\title{
Measles surveillance in Canada: Trends for 2014
}

\author{
Sherrard $L^{1 *}$, Hiebert $\mathrm{J}^{2}$, Squires $\mathrm{S}^{1}$ \\ ${ }^{1}$ Centre for Immunization and Respiratory Infectious Diseases, Public Health Agency of Canada, Ottawa, ON \\ ${ }^{2}$ National Microbiology Laboratory, Public Health Agency of Canada, Winnipeg, MB \\ ${ }^{*}$ Correspondence: lindsey.sherrard@phac-aspc.gc.ca
}

\section{Abstract}

Background: Measles elimination status was achieved in Canada in 1998. The Public Health Agency of Canada compiles evidence for the Pan American Health Organization to confirm that criteria for the verification of measles elimination continue to be met.

Objective: To describe measles activity in Canada for 2014 in order to support Canada's ongoing measles elimination status.

Methods: Using data captured by the Canadian Measles and Rubella Surveillance System and the Measles and Rubella Surveillance pilot project during 2014, the distribution of measles cases by demographics, immunization status and hospitalization were assessed, outbreak characteristics were summarized and genotypic and phylogenetic analyses were conducted and described.

Results: During 2014, 418 measles cases were reported by five provinces and territories for an overall incidence rate of 11.8 cases per $1,000,000$ population. Case counts and incidence rates were highest among those five to 14 years of age and the majority of cases were not immunized. Overall, five percent of cases were hospitalized, most frequently the youngest and oldest age groups. Eighteen outbreaks were reported, the largest of which occurred in a non-immunizing religious community in British Columbia. Genotype information was available for $98 \%$ of measles events (18/18 outbreaks and $31 / 32$ sporadic cases). Canada continued to meet or partially meet all four of PAHO's criteria for verification of measles elimination.

Conclusion: Despite significant measles activity in 2014, Canada continues to provide strong evidence that measles elimination status is being maintained.

\section{Introduction}

Measles elimination status was achieved in Canada in 1998, one year after the last endemic case was reported in 1997 (1). Since that time, the Public Health Agency of Canada (the Agency) has documented evidence to support the continued verification of measles elimination status in Canada (1, 2, 3). Measles elimination is defined as the absence of endemic measles transmission in a defined geographic area (e.g., region) for $\geq 12$ months in the presence of a well-performing surveillance system (4). This evidence is based on surveillance data collected through enhanced surveillance systems and is supported by molecular methodology. Genotyping contributes to both public health follow-up and ongoing elimination efforts by providing information on links between cases, identifying possible sources of importation and demonstrating that no single genotype is continuously circulating (i.e., absence of endemic transmission) (5).

Although the interruption of endemic measles virus transmission was achieved in the Region of the Americas in 2002 (6), endemic transmission persists across the five other World Health Organization (WHO) regions (African, Eastern Mediterranean, European, South East Asian and Western Pacific). As such, Canada is at risk of importation of the measles virus. Further, despite high immunization coverage estimates for Canada (7), outbreaks of measles continue to occur (8) as immunization coverage is heterogeneous. In order to support the 
documentation and verification of measles elimination status, the Pan American Health Organization (PAHO) has identified four essential criteria. (See text box.)

\section{Four essential criteria for verification of measles elimination (9)}

1. Verify the interruption of endemic measles cases for a period of at least 3 years from the last known endemic case, in the presence of high-quality surveillance.

2. Maintain a high-quality surveillance system sensitive enough to detect imported and import-related cases.

3. Verify the absence of endemic measles virus strains through viral surveillance.

4. Verify adequate immunization in the population.

\section{Methods}

\section{Surveillance dataset}

The Canadian Measles and Rubella Surveillance System (CMRSS) is an active, enhanced surveillance system in all Canadian provinces and territories. On a weekly basis, provinces and territories were asked by the Agency to submit a report on the number confirmed measles cases for that reporting week, or to submit a zero report. Three jurisdictions (British Columbia, Alberta and Newfoundland and Labrador) were also participating in the Measles and Rubella Surveillance (MARS) pilot project; a web-based near-real-time platform for reporting of suspect measles case investigations. All cases were assessed against the national case definition (10).

This report describes enhanced case data for confirmed measles cases with rash onset during the 2014 epidemiologic year (weeks 01 to 53, from December 29, 2013 to January 3, 2015), as reported by the provinces and territories.

\section{Case report form}

Data in CMRSS were collected using the national case report form for measles. The case report form collected information required to support the national objectives for measles surveillance in the following categories: case identifiers; background, exposure and clinical information; and laboratory information. The national case report form is available online (11).

\section{Genotyping}

All measles virus genotyping was performed at the Agency's National Microbiology Laboratory (NML). Appropriate clinical specimens (respiratory and/or urine specimens) collected from suspect or confirmed measles cases were submitted to the NML by provincial laboratories. The WHO standardized genotyping region of the 450 nucleotides encoding the carboxyl-terminus of the measles nucleoprotein, the N-450 (12) was amplified and sequenced from extracted nucleic acid. The sequences were aligned with WHO genotype reference sequences (13) and maximum parsimony phylogenetic trees were generated using MEGA6 software (14).

\section{Data management and statistical analysis}

CMRSS data were managed using Microsoft Access 2010. Blank fields were coded as missing values and fields for which a value was sought but was not available from the data source were coded as unknown. A data validation process was conducted with provinces and territories in March 2015 for all measles cases reported nationally in 2014.

The distribution of measles cases by demographics, immunization status and hospitalization were assessed. Genotypic and phylogenetic analyses were also described. Counts and proportions were determined for categorical variables, whereas means, medians or ranges were determined for continuous variables. Incidence rates were calculated using Statistics Canada July 1 population estimates for 2014 in units consistent with recommended PAHO indicators (cases per 1,000,000 population) (9). Elimination status was assessed against criteria established by PAHO (9). 
An outbreak was defined as two or more confirmed cases linked, either epidemiologically or virologically or both (11). The current publicly-funded immunization schedule in the reporting province or territory was used to define whether a case was up to date for age with measles-containing vaccine (MCV) (15) at the time of rash onset. Cases aged less than one year and those born before 1970 were age-ineligible for vaccine and were classified as up to date for age regardless of reported immunization status. Those aged seven years or more and born after 1970 were defined as up to date with two doses. Finally, for those aged one to six years, either one or two doses were considered up to date according to the current schedule in the reporting jurisdiction. Descriptive epidemiological analyses were conducted with SAS Enterprise Guide 5.1 (16). As this report utilizes public health surveillance data, it was exempt from research ethics board approval.

\section{Results}

\section{Overview}

In 2014 , a total of 418 cases of measles were reported, of which $29.2 \%(n=122)$ were laboratory-confirmed and $70.8 \%(n=296)$ were epidemiologically linked to a laboratory-confirmed case. The overall incidence for this time period was 11.8 cases of measles per $1,000,000$ population.

Cases were confined in time to a 36-week period starting in reporting week 01 (ending January 4, 2014) and continuing to week 36 (ending September 6, 2014). There was a continuous period of 17 weeks from week 37 (ending September 13, 2014) to week 53 (ending January 3, 2015) where no measles cases were reported. A maximum of $138(33.0 \%)$ cases reported for a single epidemiologic week occurred in week 12 (ending March 22, 2014) during an outbreak in British Columbia (Figure 1).

Figure 1: Number of reported measles cases, by epidemiologic week of rash onset and reporting province or territory, Canada, 2014

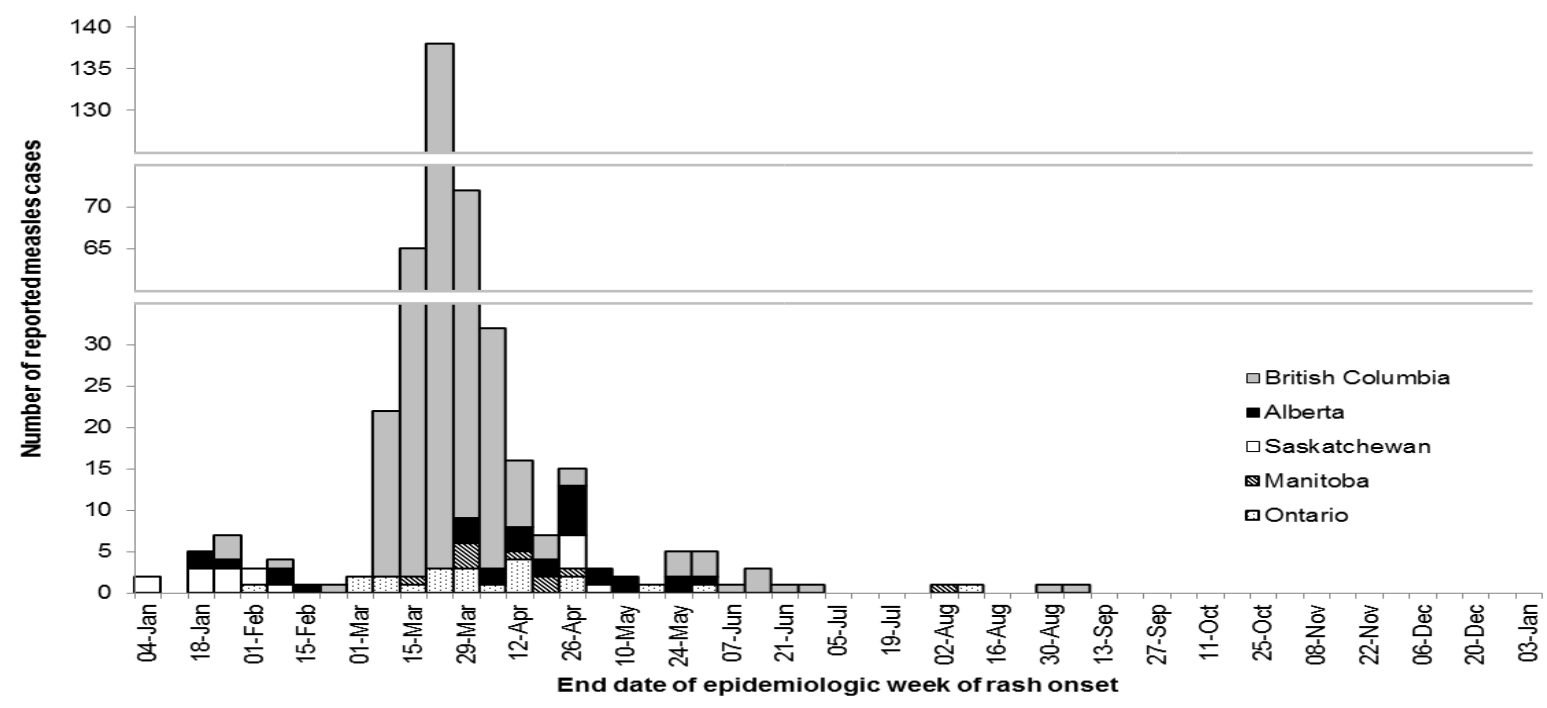




\section{Age, gender and geographic distribution}

Cases of measles were most commonly reported among those aged five to nine years $(29.9 \%)$ followed by those aged 10 to 14 years $(25.4 \%)$ and 15 to 19 years $(17.2 \%)$ (Table 1$)$.

Table 1: Confirmed measles cases and incidence rates (per 1,000,000 population) by age group, gender and reporting province or territory*, Canada, 2014

\begin{tabular}{|c|c|c|c|c|c|c|c|c|c|}
\hline Age group & $\mathbf{M}$ & $\mathbf{F}$ & $\mathbf{B C}$ & $\mathbf{A B}$ & $\mathbf{S K}$ & $\mathbf{M B}$ & $\mathbf{O N}$ & $\mathbf{C A}$ & $\begin{array}{c}\text { Overall } \\
\text { incidence rate }\end{array}$ \\
\hline$<1$ year & 10 & 4 & $4^{\dagger}$ & 4 & 3 & 0 & 3 & 14 & 36.4 \\
\hline 1 to 4 years & 13 & 12 & 17 & 3 & 2 & 1 & 2 & 25 & 16.2 \\
\hline 5 to 9 years & 64 & 61 & 118 & 3 & 3 & 0 & 1 & 125 & 65.2 \\
\hline 10 to 14 years & 56 & 50 & 100 & 3 & 2 & 0 & 1 & 106 & 56.8 \\
\hline 15 to 19 years & 31 & 41 & 62 & 5 & 0 & 2 & 3 & 72 & 33.7 \\
\hline 20 to 24 years & 15 & 12 & 23 & 2 & 0 & 1 & 1 & 27 & 10.9 \\
\hline 25 to 29 years & 8 & 3 & 8 & 1 & 0 & 1 & 1 & 11 & 4.5 \\
\hline 30 to 39 years & 13 & 11 & 7 & 4 & 5 & 1 & 7 & 24 & 5.0 \\
\hline 40 to 59 years & 6 & 8 & 3 & 4 & 1 & 3 & 3 & 14 & 1.4 \\
\hline 60 years or more & 0 & 0 & 0 & 0 & 0 & 0 & 0 & 0 & $\mathbf{4}$ \\
\hline Total & $\mathbf{2 1 6}$ & $\mathbf{2 0 2}$ & $\mathbf{3 4 2}$ & $\mathbf{2 9}$ & $\mathbf{1 6}$ & $\mathbf{9}$ & $\mathbf{2 2}$ & $\mathbf{4 1 8}$ & 11.8 \\
\hline Incidence rate: & 12.3 & 11.3 & 73.8 & 7.0 & 14.2 & 7.0 & 1.6 & 11.8 & \\
\hline
\end{tabular}

*Provinces and territories that did not report any measles cases during 2014 were omitted from the table. These were: Quebec, New Brunswick, Nova Scotia, Prince Edward Island, Newfoundland and Labrador, Yukon, Northwest Territories and Nunavut.

$\dagger$ Excluded from this count is one case of measles in a Canadian traveller who was exposed, infected and experienced the entire course of disease outside of Canada. This case is reflected in British Columbia's provincial case count.

Incidence rates were highest for those aged five to nine years, 10 to 14 years and less than one year $(65.2,56.8$ and 36.4 cases per $1,000,000$ population, respectively).

Notably, 3.3\% ( $n=14)$ of cases were reported among infants too young to have received the first dose of MCV (aged less than one year) and $1.7 \%(n=7)$ of cases were presumed to have natural immunity against measles through prior infection (born before 1970). Approximately half (51.7\%) of measles cases reported in 2014 were male.

Cases of measles were reported by five Canadian jurisdictions: British Columbia $(n=342)$, Alberta $(n=29)$, Ontario $(n=22)$, Saskatchewan $(n=16)$ and Manitoba $(n=9)$. Incidence was highest in British Columbia, followed by Saskatchewan and Alberta (73.8, 14.2 and 7.0 cases per 1,000,000 population, respectively).

\section{Immunization}

Of the 418 cases of measles reported during $2014,8.1 \%(n=34)$ were considered up to date for age with MCV at the time of rash onset (Table 2). However, $61.8 \%(n=21)$ of these cases were age-ineligible for immunization (infants aged less than one year [n=14] and adults born before 1970 [n=7]) according to the current National Advisory Committee on Immunization (NACl) recommendations (17). These were classified as up to date for age regardless of reported immunization history. Thus, overall only $3.1 \%(n=13)$ of cases were eligible to receive MCV and were considered to be up to date for age at the time of infection. 
Table 2: Immunization status of confirmed measles cases, by age group and number of doses received, Canada, 2014

\begin{tabular}{|c|c|c|c|c|c|}
\hline & 0 Doses & 1 Dose & $\geq 2$ Doses & Unknown & Total \\
\hline Age group & $\begin{array}{c}\text { (Up to date } \\
\text { with } 0 \text { doses) }\end{array}$ & $\begin{array}{l}\text { (Up to date } \\
\text { with } 1 \text { dose) }\end{array}$ & $\begin{array}{c}\text { (Up to date } \\
\text { with } \geq 2 \text { doses) }\end{array}$ & $\begin{array}{c}\text { (Up to date } \\
\text { with unknown } \\
\text { doses) }\end{array}$ & (Up to date) \\
\hline$<1$ year & $12(12)$ & $1(1)$ & $0(-)$ & $1(1)$ & $14(14)$ \\
\hline 1 to 4 years & $23(0)$ & $1(1)$ & $0(-)$ & $1(0)$ & $25(1)$ \\
\hline 5 to 9 years & $105(0)$ & $0(-)$ & $0(-)$ & $20(0)$ & $125(0)$ \\
\hline 10 to 14 years & $90(0)$ & $0(-)$ & $2(2)$ & $14(0)$ & $106(2)$ \\
\hline 15 to 19 years & $61(0)$ & $2(0)$ & $4(4)$ & $5(0)$ & $72(4)$ \\
\hline 20 to 24 years & $22(0)$ & $0(-)$ & $1(1)$ & $4(0)$ & $27(1)$ \\
\hline 25 to 29 years & $9(0)$ & $0(-)$ & $1(1)$ & $1(0)$ & $11(1)$ \\
\hline 30 to 39 years & $5(0)$ & $6(0)$ & $3(3)$ & $10(0)$ & $24(3)$ \\
\hline 40 to 59 years & $3(2)$ & $0(-)$ & $1(1)$ & $10(5)$ & $14(8)$ \\
\hline 60 years or more & $0(-)$ & $0(-)$ & $0(-)$ & $0(-)$ & $0(-)$ \\
\hline TOTAL & $330(14)$ & $10(2)$ & $12(12)$ & $66(6)$ & 418 (34) \\
\hline
\end{tabular}

Based on immunization history, $91.9 \%(n=384)$ of cases were not considered to be up to date for age, including $14.4 \%(n=60)$ with an unknown immunization history that could not be assessed. Cases not considered up to date for age with MCV were most often reported as being aged five to nine years (32.6\%), followed by 10 to 14 years $(27.1 \%)$ and 15 to 19 years $(17.7 \%)$.

One case of measles was reported in a child aged less than one year who had previously received one dose of MCV. However, vaccine was given shortly before rash onset and the case was considered to be unimmunized at the time of exposure.

Notably, three cases were reported among individuals who had received three doses of MCV. All three cases were imported from the Philippines and had received their first dose of MCV outside of Canada prior to twelve months of age.

\section{Hospitalization}

During 2014, hospitalization was indicated for 5.0\% ( $n=21)$ of reported measles cases (Table 3).

Table 3: Hospitalization status of confirmed measles cases by age group, Canada, 2014

\begin{tabular}{|c|c|c|c|c|}
\hline \multirow{2}{*}{ Age group } & \multirow{2}{*}{ Total } & Not hospitalized & Hospitalized & Unknown \\
\hline & & no. (\%) & no. $(\%)$ & no. $(\%)$ \\
\hline$<1$ year & 14 & $7(50.0)$ & $5(35.7)$ & $2(14.3)$ \\
\hline 1 to 4 years & 25 & $22(88.0)$ & $3(12.0)$ & $0(-)$ \\
\hline 5 to 9 years & 125 & $124(99.2)$ & $1(0.8)$ & $0(-)$ \\
\hline 10 to 14 years & 106 & $106(100.0)$ & $0(-)$ & $0(-)$ \\
\hline 15 to 19 years & 72 & $72(100.0)$ & $0(-)$ & $0(-)$ \\
\hline 20 to 24 years & 27 & $26(96.3)$ & $1(3.7)$ & $0(-)$ \\
\hline 25 to 29 years & 11 & $10(90.9)$ & $1(9.1)$ & $0(-)$ \\
\hline 30 to 39 years & 24 & $16(66.7)$ & $5(20.8)$ & $3(12.5)$ \\
\hline 40 to 59 years & 14 & $8(57.1)$ & $5(35.7)$ & $1(7.1)$ \\
\hline 60 years or more & 0 & $0(-)$ & $0(-)$ & $0(-)$ \\
\hline Total & 418 & 391 (93.5) & $21(5.0)$ & $6(1.4)$ \\
\hline
\end{tabular}


The youngest and oldest age groups experienced the most significant burden, with hospitalization reported for $35.7 \%(n=5)$ of cases aged less than one year, $35.7 \%(n=5)$ of cases aged 40 to 59 years and $20.8 \%(n=5)$ of cases aged 30 to 39 years. Hospitalization was infrequently reported among cases aged one to 29 years.

Note that hospitalization status was unknown for $1.4 \%(n=6)$ of cases.

\section{Molecular epidemiology}

During 2014, specimens were available to determine the genotype for $26.6 \%(n=111)$ of reported cases of measles. Cases with epidemiological links to a genotyped case are expected to have the same genotype, and so for surveillance purposes it is not necessary to genotype all cases from an outbreak. Thus in 2014, the genotype was determined for $98 \%$ of unique measles events where each outbreak or sporadic case is counted as a single event (18/18 outbreaks and 31/32 sporadic cases) far exceeding PAHO's indicator (Table 4). Measles genotypes were B3 $(n=65), D 8(n=36), D 9(n=5), H 1(n=3)$ and D4 $(n=2)$ (Figure 2).

Figure 2: Distribution of measles genotypes detected in 2014 ( $n=111)$ by week of rash onset (if available, $n=94$ ) or specimen collection $(n=17)$

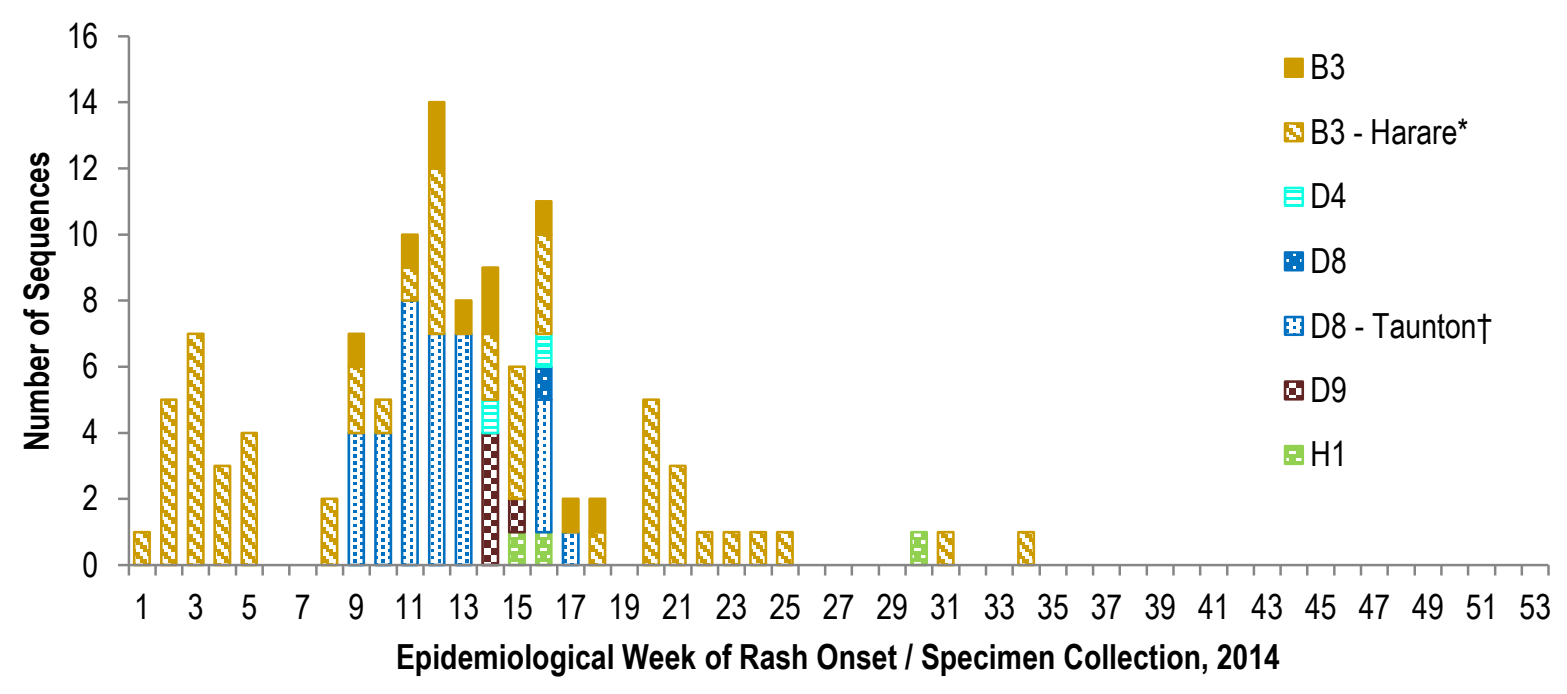

Epidemiological weeks are assigned in accordance with WHO guidelines (WHO.WER.2012;9(87):73) with week one beginning on the first Monday of the year.

*Genotype B3 sequences identical to sequence variant MVi/Harare.ZWE/38.09 (GenBank accession number JF973033).

$\dagger$ Genotype D8 sequences identical to sequence variant MVs/Taunton.GBR/27.12 (GenBank accession number JX984461).

Measles genotype B3 was circulating globally and was reported in over 40 countries in 2014 (18). In Canada, it was detected in 65 cases; $58.5 \%(n=38)$ of which were associated with 12 outbreaks (Appendix). It was most frequently imported from the Philippines $(n=16)$ but was also identified in cases with travel history to USA $(n=1)$, Europe $(n=1)$, Pakistan $(n=1)$ and Thailand $(n=1)$. Fifty-five of the 65 genotype B3 N-450 sequences were identical to MVi/Harare.ZWE/38.09 (GenBank accession number JF973033), also known as the B3-Harare sequence variant (Figure 3). This sequence variant was reported globally and frequently linked with the Philippines, where there was a large outbreak in 2014 (GenBank accession number KJ634500). All Canadian cases with travel history to the Philippines had N-450 sequences identical to the B3-Harare sequence variant $(n=13)$ or differed only by one nucleotide $(99.8 \%$ identical, $n=3)$. B3 sequence variants imported from places other than the Philippines differed from the B3-Harare sequence variant by one $(99.8 \%$ identical, imported from USA, $n=1)$, two $(99.6 \%$ identical, imported from Thailand, $n=1)$ or three nucleotides $(99.3 \%$ identical, imported from Pakistan, $n=1$ ), providing laboratory confirmation that they were indeed unrelated measles events, imported from multiple sources. 
Figure 3: Phylogenetic tree of measles N-450 sequences detected in Canada in 2014 (n=111)

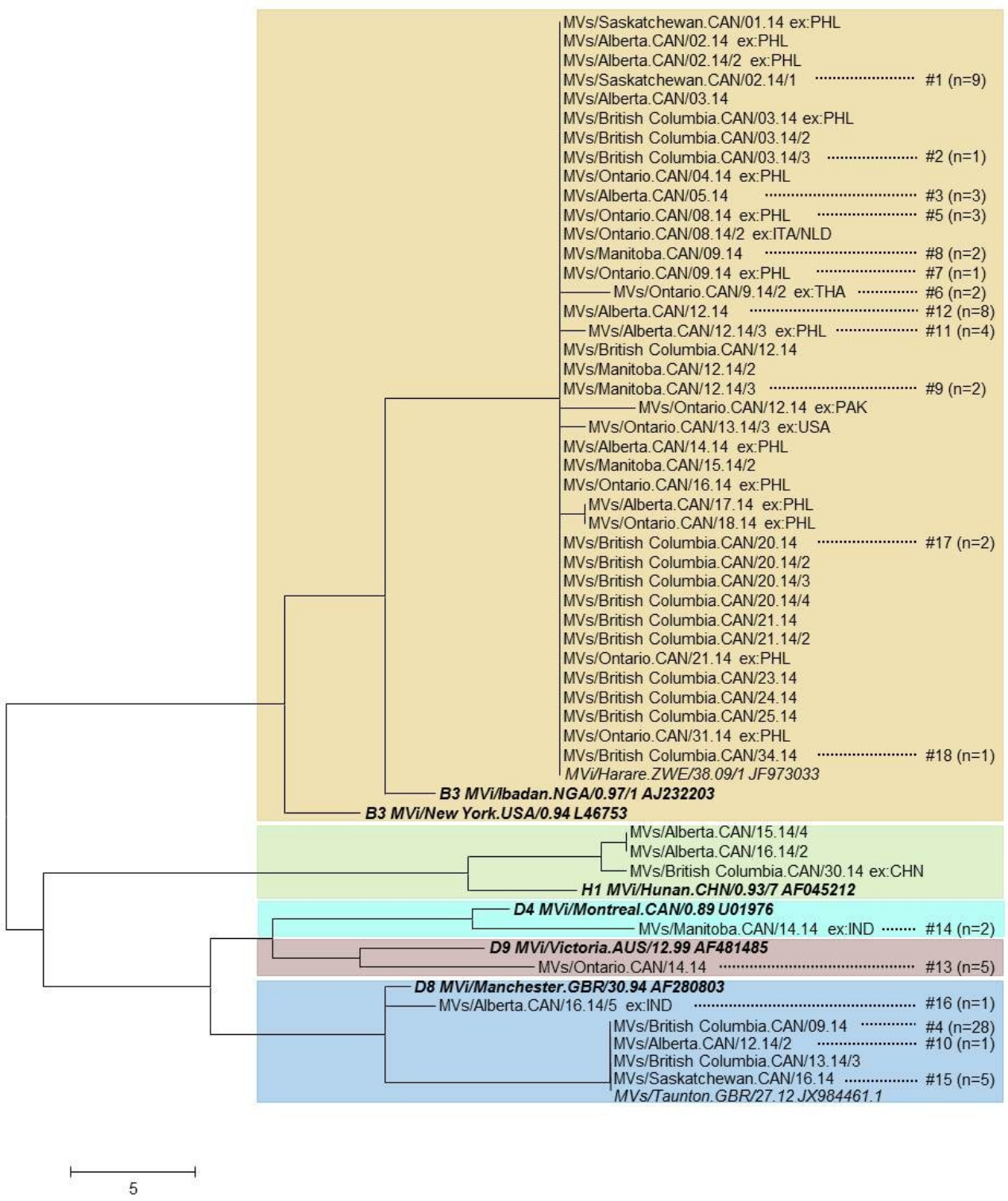

LEGEND:

Relevant WHO reference sequences (13) are shown in bold, italic font. Sequence variants, assigned in the WHO measles sequence database (MeaNS) (20), are shown in italics. Canadian sequences are shown in regular font and are identified by their WHO name which indicates province and week of rash onset or specimen collection. Cases with travel history are identified with "ex: $<3$ letter country code $>$." Outbreaks are represented by a single sequence and are tagged with their outbreak number (Appendix). The number of identical sequences identified in the outbreak is provided in brackets. The remaining sequences (without an outbreak number listed) are from sporadic cases $(\mathrm{n}=31)$.

Measles genotype D8 was detected in 36 cases; 88.9\% $(n=32)$ of which were associated with four outbreaks including the large outbreak in BC (Appendix). Nearly all of the $N-450$ sequences $(n=35)$ (many of which were associated with three outbreaks) were identical to the MVs/Taunton.GBR/27.12 sequence variant (GenBank accession number JX984461) (Figure 3). Globally, this genotype D8 sequence variant had been associated with a large, long-lasting outbreak in the Netherlands that began in 2013 (19). A second strain of genotype D8 was identified in 2014, associated with a small outbreak originating from India, where genotype D8 is endemic (20) (Figure 3, Appendix). 
Outbreaks that were reported ranged in size from two to 325 cases (median: three cases). The majority (72.2\%) of outbreaks were two generations or less and the median duration was 15 days (two generations). Reported outbreaks were determined to be genotypes B3 $(n=12)$, D8 $(n=4)$, D4 $(n=1)$ and D9 $(n=1)$.

The vast majority $(84.4 \%, n=325)$ of outbreak-related cases occurred during a large outbreak of measles in British Columbia. This outbreak occurred in a non-immunizing religious community, where it is suspected that the source of the virus was an undocumented importation from the Netherlands, the location of a concurrent outbreak (19) in a religious community with historic precedent for importation of vaccine preventable diseases into Canada $(1,21,22)$. This outbreak occurred predominantly among those aged five to 14 years. Further analysis of this outbreak is described elsewhere (8).

\section{Canadian measles in the global context}

Among the 418 measles cases reported in 2014, 6.0\% ( $n=25)$ were imported. The majority of importations acquired disease in the Western Pacific region (the Philippines [ $n=18]$, China [ $n=1]$ ), followed by the South East Asian region (India [n=2], Thailand [n=1]), the Eastern Mediterranean region (Pakistan [ $n=1]$ ), the European region (Italy/ Netherlands [ $n=1]$ ) and the Region of the Americas (United States [ $n=1]$ ). The Philippines experienced a significant outbreak of measles in 2014, presumably a driver of the volume of importations that Canada experienced in that year.

Of the 25 reported importations, only nine (originating from the Philippines [ $n=6]$, India [ $n=2$ ] and Thailand [ $n=1]$ ), are known to have resulted in secondary spread. All of the reported importations were individuals whose country of usual residence was Canada, who acquired measles during travel and were infectious following their return to Canada. Further, importations were distributed across almost every age group, but were most commonly reported among those aged less than one year or 15 to 19 years $(16 \%, n=4$ each).

\section{Maintenance of measles elimination}

$\mathrm{PAHO}$ has established four essential criteria for the ongoing verification of measles elimination (9). Canada met or partially met all of these criteria in 2014 (Table 4).

\section{Table 4: Pan American Health Organization essential criteria for the verification of measles} elimination

\begin{tabular}{|c|c|c|}
\hline Criterion & Indicator & Description \\
\hline $\begin{array}{l}\text { Verify the interruption of } \\
\text { endemic measles cases for a } \\
\text { period of at least } 3 \text { years from } \\
\text { the last known endemic case in } \\
\text { the presence of high-quality } \\
\text { surveillance }\end{array}$ & $\begin{array}{l}\text { Zero cases of } \\
\text { endemic transmission }\end{array}$ & $\begin{array}{l}\text { Criterion met } \\
\text { Canada achieved measles elimination status in 1998. Since } \\
\text { then, molecular and epidemiological surveillance continues to } \\
\text { demonstrate that no viral strain has circulated for a period of } \\
\text { one year or more in Canada. } \\
\text { Previously-presented evidence supporting the verification of } \\
\text { interruption of endemic measles in Canada from } 1998 \text { to } \\
2013 \text { is available online }(1,2,3) \text {. }\end{array}$ \\
\hline $\begin{array}{l}\text { Maintain high-quality } \\
\text { surveillance sensitive enough to } \\
\text { detect imported and import- } \\
\text { related cases }\end{array}$ & $\begin{array}{l}>2 \text { suspect cases per } \\
100,000 \text { population } \\
\text { adequately } \\
\text { investigated }\end{array}$ & $\begin{array}{l}\text { Criterion partially met } \\
\text { As only confirmed cases of measles are nationally notifiable } \\
\text { in Canada, this indicator cannot be directly assessed. } \\
\text { However, using data obtained by the Measles and Rubella } \\
\text { Surveillance Pilot Project, the national rate of measles-like } \\
\text { illness investigation rate was estimated to be between } 12 \text { per } \\
100,000 \text { population ( } 2006, \text { non-outbreak year) and } 19 \text { per } \\
100,000 \text { population ( } 2011, \text { outbreak year). }\end{array}$ \\
\hline $\begin{array}{l}\text { Verify the absence of endemic } \\
\text { measles virus strains through } \\
\text { viral surveillance }\end{array}$ & $\begin{array}{l}\text { Measles genotype } \\
\text { assessed in } 80 \% \text { of } \\
\text { outbreaks }\end{array}$ & Criterion met \\
\hline
\end{tabular}




\begin{tabular}{|l|l|l|}
\hline $\begin{array}{l}\text { Verify adequate immunization } \\
\text { in the population }\end{array}$ & $\begin{array}{l}2014 . \\
\begin{array}{l}\text { 95\% of population } \\
\text { cohorts aged 1 to 40 } \\
\text { years have received a } \\
\text { measles-containing } \\
\text { vaccine }\end{array}\end{array}$ & $\begin{array}{l}\text { Criterion partially met } \\
\text { A national immunization registry does not currently exist in } \\
\text { Canada; therefore this criterion cannot be directly assessed. }\end{array}$ \\
$\begin{array}{l}\text { However, the 2011 Childhood National Immunization } \\
\text { Coverage Survey estimated first dose MCV coverage among } \\
\text { 2 year olds to be 95.2\% and second dose MCV coverage } \\
\text { among 7 year olds to be 94.9\% (7). However, note that these } \\
\text { are average values; coverage is heterogeneous and will be } \\
\text { higher in some areas and lower in others }\end{array}$ \\
\hline
\end{tabular}

\section{Discussion}

During 2014, there were 418 confirmed cases of measles reported in Canada, the second-highest total since measles elimination was achieved in 1998. In large part however, these cases were attributable to an outbreak in a non-immunizing religious community (8). Notably, the majority (72.2\%) of outbreaks in 2014 were limited to two generations or less, with the median duration for an outbreak being 15 days (two generations). This suggests that these events were well-controlled by a combination of high immunization coverage rates and interventions implemented by public health.

The burden of measles was highest among those aged five to 14 years in terms of the incidence of disease, corresponding to the age group distribution of cases reported during an outbreak in British Columbia in a nonimmunizing religious community. However, the burden was also appreciable for those aged less than one year and 40 to 59 years, with respect to morbidity (i.e., hospitalization). Given the limitations of morbidity data captured by CMRSS and MARS and the absence of mortality data, this is an incomplete representation of the true burden of disease caused by measles in Canada.

Five genotypes (B3, D8, D9, H1 and D4) were detected in 2014, imported from every WHO region except the African region. While Canada achieved measles elimination status in 1998, importations of measles will continue to occur as the virus circulates widely in other countries. According to the WHO, over 201,000 confirmed cases of measles were reported worldwide in 2014, primarily in the Western Pacific region (23). The United States also reported the highest yearly total of measles cases since they achieved elimination in 2000 (24). Global travel coupled with significant outbreaks in other areas of the world can increase the risk of importation and subsequently the opportunity for the spread of measles within Canada. Large domestic outbreaks, such as the one reported by British Columbia, highlight areas for improvement in population-level immunity and the ongoing importance of maintaining high immunization coverage with MCV.

As in previous years, Canada met or partially met all of the criteria for verification of measles elimination set out by PAHO. Genotyping was completed for $98 \%$ of unique measles events in 2014 . Molecular methods continue to play a key role in supporting epidemiologic surveillance for the criteria Canada met in 2014: verifying the interruption of endemic measles cases for a period of at least three years from the last known endemic case, in the presence of high-quality surveillance and verifying the absence of endemic measles virus strains through viral surveillance. The criteria Canada partially met (maintaining high-quality surveillance sensitive enough to detect imported and import-related cases and verifying adequate immunization in the population) present opportunities to strengthen current activities related to Canada's ongoing commitment to measles elimination, summarized elsewhere (25).

\section{Limitations}

Measles-related mortalities are not currently captured by CMRSS or MARS. However, it is likely that death following acute measles infection would be described by alternative sources of information (e.g., Statistics Canada's Vital Statistics or the media). While limited morbidity data are available, detailed information such as duration of hospitalization or the nature and severity of any complication are not currently described by CMRSS or MARS. 
Immunization status could not be assessed for $14.4 \%(n=60)$ of cases. Further, immunization status for cases aged one to six years was defined using the current provincial or territorial schedule which differs across jurisdictions. While this respects the health context in which the case occurred, it differentiates between similar individuals based on a factor that may not contribute to their vulnerability to measles.

\section{Conclusion}

Despite significant measles activity in 2014 , Canada continues to provide strong evidence for maintained measles elimination status.

\section{Acknowledgements}

The authors gratefully acknowledge the continued cooperation and efforts of our provincial and territorial partners for providing and validating data captured by CMRSS and MARS and for their review of the report content.

The authors are also grateful to NML staff, particularly staff of the Genomics Core Services and the Viral Exanthemata section (Dr. Alberto Severini, Lillian Mendoza and Lisa Podhorodecki) for their contribution in generating the molecular data and to provincial laboratories for providing the specimens.

\section{Conflict of interest}

None

\section{Funding}

This work was supported by the Public Health Agency of Canada.

\section{References}

(1) King A, Varughese P, De Serres G, Tipples GA, Waters J. Working Group on Measles Elimination. Measles elimination in Canada. J Infect Dis. 2004 May 1;189 Suppl 1:S236-42.

(2) Public Health Agency of Canada. Elimination of measles, rubella and congenital rubella syndrome in Canada: Documentation and verification report. Ottawa ON: Public Health Agency of Canada; 2011.

(3) Shane A, Hiebert J, Sherrard L, Deehan H. Measles surveillance in Canada: Trends for 2013. CCDR. 2014;40(12):219.

(4) World Health Organization (WHO). Monitoring progress towards measles elimination. Wkly Epidemiol Rec. 2010 Dec 3;85(49):490-4). http://www.who.int/wer/2010/wer8549.pdf.

(5) Hiebert J, Severini A. Measles molecular epidemiology: What does it tell us and why is it important? CCDR. 2014;40(12):257.

(6) Castillo-Solorzano C, Matus C, Flannery B, Marsigli C, Tambini G, Andrus J. The Americas: Paving the road toward global measles eradication. J Infect Dis. 2011;204(Suppl 1):S270.

(7) Public Health Agency of Canada. Vaccine coverage in Canadian children: Results from the 2011 Childhood National Immunization Coverage Survey. Ottawa ON: Public Health Agency of Canada; 2014. http://www.phac-aspc.gc.ca/im/nics-enva/vccc-cvec-eng.php.

(8) Pan American Health Organization (PAHO). Plan of action. Documentation and verification of measles, rubella and congenital rubella syndrome elimintation in the Region of the Americas. Technical Document. Washington DC: PAHO; 2010.

(9) Naus M, Puddicombe D, Murti M, Fund C et al. Outbreak of measles in an unvaccinated population, British Columbia, 2014. CCDR. 2015; 41:7 (171-177).

(10) Public Health Agency of Canada. Case definitions for diseases under national surveillance. CCDR. 2009;35(S2). http://www.phac-aspc.gc.ca/publicat/ccdr-rmtc/09vol35/35s2/index-eng.php.

(11) Public Health Agency of Canada. Guidelines for the prevention and control of measles outbreaks in Canada. CCDR. 2013;39:ACS3.

(12) World Health Organization (WHO). Standardization of the nomenclature for describing the genetic characteristics of wild-type measles viruses. Wkly Epidemiol Rec. 1998;73:265.

(13) World Health Organization (WHO). Measles virus nomenclature update: 2012. Wkly Epidemiol Rec. $2012 ; 9(87): 73$.

(14) Tamura K, Peterson D, Peterson N, Stecher G, Nei M, Kumar S. Molecular evolutionary genetics analysis using maximum likelihood, evolutionary distance, and maximum parsimony methods. Mol Biol Evol. 2011;28:2731.

(15) Public Health Agency of Canada, Canadian Nurses Coalition on Immunization. [Internet] 
Publicly-funded immunization programs in Canada: Routine schedule for infants and children including special programs and catch-up programs. Ottawa ON: Public Health Agency of Canada; 2015. http://www.phacaspc.gc.ca/im/ptimprog-progimpt/table-1-eng.php.

(16) SAS Global Forum 2014. SAS Enterprise Guide 5.1. 2013;5.1.

(17) National Advisory Committee on Immunization (NACI). Canadian immunization guide. Part 4: Active vaccines measles vaccine. Ottawa ON: Public Health Agency of Canada; 2012. http://www.phac-aspc.gc.ca/publicat/ciggci/p04-eng.php.

(18) World Health Organization (WHO) [Internet]. Measles surveillance data. Geneva: World Health Organization; 2015. http://www.who.int/immunization/monitoring_surveillance/burden/vpd/surveillance_type/active/measles_monthlydata/ en/index1.html.

(19) Knol M, Urbanus A, Swart E, Mollema L, Ruijs W, van Vinnendijk R, et al. Large ongoing measles outbreak in a religious community in the Netherlands since May 2013. Euro Surveill. 2013 Sep 5;18(36).

(20) Rota PA, Brown K, Mankertz A, et al. Global distribution of measles genotypes and measles molecular epidemiology. J Infec Dis. 2011;204(Suppl1):8514.

(21) Hahné S, Macey J, van Binnendijk R, Kohl R, Dolman S, van der Veen Y, et al. Rubella outbreak in the Netherlands, 2004-2005: High burden of congenital infection and spread to Canada. Pediatr Infect Dis J. 2009 Sep;28(9):795-800.

(22) Wielders C, van Binnendijk R, Snijders B, Tipples GA, Cremer J, Fanoy E, et al. Mumps epidemic in orthodox religious low-vaccination communities in the Netherlands and Canada, 2007 to 2009. Euro Surveill. 2011 Oct 13;16(41).

(23) World Health Organization (WHO) WHO Measles Surveillance Data. Geneva: WHO; 2015. http://www.who.int/immunization/monitoring_surveillance/burden/vpd/surveillance_type/active/measlesregionalsumm ary.pdf?ua=1.

(24) Gastanaduy P, Redd SB, Parker Fiebelkorn A, Rota JS, Rota PA, Bellini WJ, et al. Measles - United States, January 1 - May 23, 2014. MMWR. 2014 Jun 6;63(22):496.

(25) Lam P-P, Williams L, Gadient S, Squires S, St-Laurent M. Maintaining measles elimination in Canada: Moving forward. CCDR. 2015; 41:7 (178-181).

Appendix: Summary of measles outbreaks in Canada, ordered by earliest date of rash onset, 2014

\begin{tabular}{|c|c|c|c|c|c|}
\hline$\#$ & Prov. & $\begin{array}{l}\text { No. } \\
\text { of } \\
\text { cases }\end{array}$ & $\begin{array}{l}\text { Duration (in } \\
\text { days) } \\
\text { (Generations) }\end{array}$ & Genotype & Description \\
\hline 1 & SK & 10 & $\begin{array}{l}32 \\
(3)\end{array}$ & $\begin{array}{c}\text { B3 - } \\
\text { Harare* }^{*}\end{array}$ & $\begin{array}{l}\text { - The index case was an importation from the Philippines } \\
\text { in an unimmunized Canadian traveller. } \\
\text { Subsequent spread was reported among contacts in a } \\
\text { variety of settings. }\end{array}$ \\
\hline 2 & $\mathrm{BC}$ & 2 & $\begin{array}{l}14 \\
(2)\end{array}$ & $\begin{array}{c}\text { B3 - } \\
\text { Harare* }^{*}\end{array}$ & $\begin{array}{l}\text { - The index case in this outbreak had an unknown source } \\
\text { of exposure. } \\
\text { The secondary case was epidemiologically linked to the } \\
\text { index case. }\end{array}$ \\
\hline 3 & $A B$ & 3 & $\begin{array}{c}4 \\
(1)\end{array}$ & $\begin{array}{c}\text { B3 - } \\
\text { Harare* }\end{array}$ & $\begin{array}{l}\text { - The primary case was not identified. } \\
\text { - This cluster of three cases were presumed to have } \\
\text { shared a common source of exposure based on their } \\
\text { dates of rash onset. }\end{array}$ \\
\hline 4 & $B C$ & 325 & $\begin{array}{l}107 \\
(9)\end{array}$ & $\begin{array}{c}\text { D8 - } \\
\text { Taunton† }\end{array}$ & $\begin{array}{l}\text { - The primary case was not reported, but was believed to } \\
\text { have been an importation from the Netherlands. } \\
\text { Subsequent spread occurred within a non-immunizing } \\
\text { religious community primarily in a school-based setting. } \\
\text { - Very few cases related to this outbreak were reported } \\
\text { outside of the religious community. }\end{array}$ \\
\hline 5 & ON & 4 & $\begin{array}{l}26 \\
(3)\end{array}$ & $\begin{array}{c}\text { B3 - } \\
\text { Harare* }^{*}\end{array}$ & $\begin{array}{l}\text { - The index case in this outbreak was an importation from } \\
\text { the Philippines in an unimmunized child. } \\
\text { The secondary cases were household and school } \\
\text { contacts. }\end{array}$ \\
\hline
\end{tabular}




\begin{tabular}{|c|c|c|c|c|c|}
\hline 6 & ON & 2 & $\begin{array}{l}12 \\
(2)\end{array}$ & B3 & $\begin{array}{l}\text { - The index case in this outbreak was an importation from } \\
\text { Thailand in an immunized Canadian traveller. } \\
\text { - The secondary case was a household contact of the case. }\end{array}$ \\
\hline 7 & ON & 3 & $\begin{array}{l}19 \\
(2)\end{array}$ & $\begin{array}{c}\text { B3 - } \\
\text { Harare* }^{*}\end{array}$ & $\begin{array}{l}\text { - The index case in this outbreak was an importation from } \\
\text { the Philippines, who also travelled to China. } \\
\text { - The two secondary cases were exposed to measles in a } \\
\text { health care setting. }\end{array}$ \\
\hline 8 & $\mathrm{MB}$ & 2 & $\begin{array}{l}15 \\
(2)\end{array}$ & $\begin{array}{c}\text { B3 - } \\
\text { Harare* }\end{array}$ & $\begin{array}{l}\text { - The index case in this outbreak had an unknown source } \\
\text { of exposure. } \\
\text { - The secondary case was a close household contact of the } \\
\text { index case. }\end{array}$ \\
\hline 9 & $\mathrm{MB}$ & 2 & $\begin{array}{l}21 \\
(2)\end{array}$ & $\begin{array}{c}\text { B3 - } \\
\text { Harare* }^{*}\end{array}$ & $\begin{array}{l}\text { - The index case in this outbreak had an unknown source } \\
\text { of exposure. } \\
\text { - The secondary case was exposed in a healthcare setting. }\end{array}$ \\
\hline 10 & $A B$ & 2 & $\begin{array}{c}5 \\
(1)\end{array}$ & $\begin{array}{c}\text { D8 - } \\
\text { Taunton† }\end{array}$ & $\begin{array}{l}\text { - The primary case for this outbreak was unknown. } \\
\text { - The two reported cases were epidemiologically linked } \\
\text { and were presumed to have a common source of } \\
\text { exposure. }\end{array}$ \\
\hline 11 & $A B$ & 4 & $\begin{array}{l}27 \\
(3)\end{array}$ & B3 & $\begin{array}{l}\text { - The index case was an importation from the Philippines } \\
\text { in an unimmunized Canadian. } \\
\text { - The secondary cases were import-related, } \\
\text { epidemiologically-linked cases in the same health unit. }\end{array}$ \\
\hline 12 & $A B$ & 9 & $\begin{array}{l}53 \\
(5)\end{array}$ & $\begin{array}{c}\text { B3 - } \\
\text { Harare* }^{*}\end{array}$ & $\begin{array}{l}\text { - This event includes two simultaneous importations from } \\
\text { the Philippines (recent immigrants who travelled } \\
\text { together). } \\
\text { - The secondary cases were import-related cases. }\end{array}$ \\
\hline 13 & ON & 5 & $\begin{array}{l}12 \\
(1)\end{array}$ & D9 & $\begin{array}{l}\text { - The index case was a visitor from China epidemiologically } \\
\text { linked to an ongoing outbreak there. } \\
\text { - All five cases were epidemiologically linked to this one } \\
\text { visitor. }\end{array}$ \\
\hline 14 & $\mathrm{MB}$ & 2 & $\begin{array}{l}13 \\
(2)\end{array}$ & D4 & $\begin{array}{l}\text { - The index case in this outbreak was imported from India. } \\
\text { - The secondary case had a weak epi-link to the index } \\
\text { case. }\end{array}$ \\
\hline 15 & SK & 5 & $\begin{array}{c}9 \\
(2)\end{array}$ & $\begin{array}{c}\text { D8 - } \\
\text { Taunton† }\end{array}$ & $\begin{array}{l}\text { - The primary case for this event was not identified, but is } \\
\text { presumed to be the common source of exposure for the } \\
\text { reported cases. } \\
\text { - The reported cases compose two clusters with no travel } \\
\text { or source of exposure identified. }\end{array}$ \\
\hline 16 & $A B$ & 2 & $\begin{array}{l}13 \\
(2)\end{array}$ & D8 & $\begin{array}{l}\text { - The index case in this outbreak was an importation from } \\
\text { India. } \\
\text { The secondary case was epidemiologically linked to the } \\
\text { index case. }\end{array}$ \\
\hline 17 & BC & 2 & $\begin{array}{l}18 \\
(2)\end{array}$ & $\begin{array}{c}\text { B3 - } \\
\text { Harare* }\end{array}$ & $\begin{array}{l}\text { - The index case had an unknown source of exposure. } \\
\text { - The secondary case was exposed in a health care setting. }\end{array}$ \\
\hline 18 & $B C$ & 2 & $\begin{array}{c}9 \\
(2)\end{array}$ & $\begin{array}{c}\text { B3 - } \\
\text { Harare* }^{*}\end{array}$ & $\begin{array}{l}\text { - The index case had an unknown source of exposure. } \\
\text { - } \quad \text { The secondary case was a household contact. }\end{array}$ \\
\hline
\end{tabular}

*Genotype B3 sequences identical to sequence variant MVi/Harare.ZWE/38.09 (GenBank accession number JF973033).

$\dagger$ Genotype D8 sequences identical to sequence variant MVs/Taunton.GBR/27.12 (GenBank accession number JX984461). 